\title{
Domestic Violence and Its Related Factors Based a Prevalence Study in Iran
}

\author{
Zahra Abbaspoor $^{1} \&$ Mozhgan Momtazpour ${ }^{2}$ \\ ${ }^{1}$ Department of Midwifery, Reproductive Health Promotion Research Center, Ahvaz Jundishapur University of \\ Medical Sciences, Ahvaz, Iran \\ ${ }^{2}$ Department of Midwifery, Falavarjan Branch, Islamic Azad University, Isfahan, Iran \\ Correspondence: Mozhgan Momtazpour, Ms in Midwifery, Member of Faculty, Department of Midwifery, \\ Falavarjan Branch, Islamic Azad University, Isfahan, Iran. Tel: 98-91-3206-7266. E-mail: \\ momtazpour85s@yahoo.com
}

Received: November 26, 2015 Accepted: April 20, 2016 Online Published: April 29, 2016

doi:10.5539/gjhs.v8n12p1 URL: http://dx.doi.org/10.5539/gjhs.v8n12p1

\begin{abstract}
The aim of present study was to assess the frequency of violence against married women and its related factors in health centers affiliated to Isfahan University of medical sciences.

This is a cross-sectional study was conducted on married women who were attending in health centers in Isfahan city, Iran. Woman Abuse scale was used to illicit information regard to violence and a structured questionnaire was used to gathering data regard to socio demographic characteristics. Out of the total 600 women $(61.7 \%)$ reported positive domestic violence.

Psychological, physical, sever (life threatened) and sexual violence was found to be $59.7 \%, 33.2 \%, 10 \%$ and $39.3 \%$ respectively. Significant difference was found between violence and some socio demographic characteristics including: age, years of marriage, occupation, education, smoking, number of children, satisfaction with baby sex and socio economic status $(\mathrm{p}<0.05)$.

Prevalence of domestic violence is high in Isfahan city. Thus, the health providers should be trained to help and support victims through providing referral services and also adequate treatment to making a positive difference in their lives.
\end{abstract}

Keywords: domestic violence, women, prevalence, reproductive factors

\section{Introduction}

Violence against women is define as any act of gender-based violence that results in physical, sexual or mental harm to women (Assembly, 1993). Domestic violence also known as intimate partner abuse, family violence, wife beating, battering, marital abuse, and partner abuse-is an international problem (Campbell, 2002; Krug, Dahlberg, Mercy, Zwi, \& Lozano, 2002). Most research to assess the prevalence of intimate partner violence focuses on compiling information on respondents' exposure to a range of physical, sexual and emotional/ psychological acts of violence by an intimate partner (Organization, 2013). Because of a widespread hesitancy amongst most experienced violence women to report, domestic violence remained hidden for a long times (Jejeebhoy, 1998) and its prevalence is reported still scarce in many countries, especially in the developing world (Krug, Mercy, Dahlberg, \& Zwi, 2002; of, Council of Europe, 2012). Studies conducted in ten Countries (Bangladesh, Brazil, Ethiopia, Japan, Namibia, Peru, Samoa, Serbia and Montenegro, Thailand and the United Republic of Tanzania) indicated that $15 \%$ to $71 \%$ women in these countries experience physical, or/and sexual partner violence in their lifetime (Garcia-Moreno, Jansen, Ellsberg, Heise, \& Watts, 2006). The prevalence of this problem in the USA estimated as varying between $17.4 \%$ and $25.5 \%$ (Mailey-Morrison \& Hines, 2004) and in Europe it is between 10\% and 50\% (Machado, Dias, \& Coelho, 2010). Based on Anderson study, 14\% of men and $18 \%$ of women reported being a victim of partner physical violence in the last year (Andersson, Ho-Foster, Mitchell, Scheepers, \& Goldstein, 2007). In limited researches conducted in Iran, prevalence of domestic violence was varied between $40 \%$ in Babol city to $92 \%$ in Bandar Abbas city (Derakhshanpour, Mahboobi, \& Keshavarzi, 2014; Faramarzi, 2004). Wife abuse involving sever consequences for victims, their families and society as a whole (Correia, Alves, Morais, \& Ramos, 2015). It may lead to female morbidity and mortality and 
causes psychological trauma, depression, injuries, sexually transmitted diseases, suicide and death of women in the world (Astin, Lawrence, \& Foy, 1993; Avdibegović \& Sinanović, 2006; Campbell et al., 2002; Guth \& Pachter, 2000; Scholle, Rost, \& Golding, 1998). In various studies domestic violence was related to some factors. In a study conducted by Anderson et al., there was a association between domestic violence with having multiple partners, other association included the income gap within households, negative attitudes about sexuality, potentially dangerous attitudes to HIV infection, but there was no association with age, income, education, household size, occupation and alcohol abuse among the women (Andersson et al., 2007). In the other study, the strongest association with injury from domestic violence was having a former partner and there was not a significant association with more than a high-school education. For male partners, alcohol consumption was associated with the risk of inflicting injury as a result of domestic violence (Kyriacou et al., 1999). Total household income, unemployed, Food security, attitudes about sexuality and sexual violence, and beliefs about gender violence were the other effective factors (Jewkes, Levin, \& Penn-Kekana, 2002). In addition, viral infections such as influenza, STDs, fibroids, pelvic pains, vaginal discharge and vaginal bleeding in women affected by domestic violence are greater than not affected women (Campbell et al., 2002). Also, it estimated that about 8800000 children annually are witness of violence between their parents in USA (Sherkat, 2004). Because of the destructive outcomes of violence on women, their family members and society, and also because of that, wife abuse is a serious threat and a hidden damage for women's health, this study carried on women to assess the frequency and related factors of domestic violence in health centers of Isfahan, Iran.

\section{Materials and Methods}

This cross-sectional study was conducted in the health centers related to Isfahan University of medical sciences, Isfahan, in center of Iran, in Jan. to July 2013. The subjects were recruited by using cluster sampling method. At first Isfahan divided to two clusters. Then 6 health centers from each cluster were selected randomly, after that, 50 women from each health centers were selected randomly according to the odds and even numbers for health documents. All the women were interviewed at the clinic making a total of 600 study subjects. The women who were married, were $\geq 15$ years old and gave written informed consent were included in the study and the anonymity of subjects was maintained. Those women with any kind of psychiatric disorder, on any kind of medication were excluded. A structured socio-demographic questionnaire and the Woman Abuse scale were used for data collection. The socio demographic information included information about age, years of marriage, occupation, education, smoking, number of children, and satisfaction with baby sex and also, socio economic status. Domestic violence was assessed by using "women abuse scale" with three components-physical, psychological and severs (life threatened) violence. This scale is a revised conflict tactics scale version (CTS) as the most widely used instrument for identifying domestic violence and measuring violence against a partner in a dating or marital relationship. Sexual violence also was assessed by using the revised conflict tactics Scale (CTS2). This scale measure victimization and conflicts between partners: physical assault, psychological aggression; and negotiation; and scales to measure injury and sexual coercion of and by a partner (Straus, Hamby \& Warren, 2003). Validity and reliability of scales were stablished in Iranian population (Dolatian et al., 2010; Panaghi et al., 2011).

The positive response to each question considered as violence. The clinical examination and interview were carried out by a single trained midwife (first investigator) who before was trained by a specialist physician in emergency. To reducing the bias, the interview was taken in a separate room in health center where only subject and interviewer were allowed. After interview, women were referred to emergency physician for taking care and treatment and other required follow ups. Data analysis was carried out using the Statistical Package for Social Sciences (SPSS) version 19. For describing data descriptive statistics was used. To assess the association of socio-demographic factors with violence, the chi-square and t tests were used. Percentage of responses was calculated for each component (psychological, physical, life threatened and sexual). The level of significance was set at 0.05 .

\section{Ethical Considerations}

This study was approved by the Research Ethics Committee of Ahvaz Jundishapur University of Medical Sciences, Ahvaz, Iran. Women filled up informed written consent form. Each woman was assigned an ID code, ensuring data set anonymity.

\section{Results}

Out of the total 600 women, $370(61.7 \%)$ reported domestic violence in some form i.e. psychological, physical, sever (life threatened) or sexual and 230 (38.3\%) reported no domestic violence. Percentage of subjects who reported psychological, physical, sever (life threatened) and sexual violence has shown in Table 1. 
Table 1. Comparison of different forms of domestic violence between domestic violence and no domestic violence groups

\begin{tabular}{llll}
\hline Voilence & Voilence group & No voilence group & Total \\
\hline & No. $(\%)$ & No. $(\%)$ & \\
\hline Psychological & $358(59.7)$ & $242(40.3)$ & $600(100)$ \\
Physical & $199(33.2)$ & $401(66.8)$ & $600(100)$ \\
Life threatening (Severe) & $60(10)$ & $540(90)$ & $600(100)$ \\
Sexual & $236(39.3)$ & $364(60.7)$ & $600(100)$ \\
\hline
\end{tabular}

Table 2 compares the socio-demographic information of both groups. There was no significant difference between women and men' ages, years of marriage, husband' Job, hhusband's consume alcohol, in two groups. There was a significant relationship between wife and husband' education, wife' Job, husband's smoking, number of children, husband' satisfaction with baby sex, and economic status in women views point. Results showed that families with lower wife and husband' education, marital age of women and economical status in domestic violence group was found to be poorer than the non-domestic violence group. In addition, to be housewife, to be smoker, not to be satisfied with his babies sex (to be girl) of husband and having 3 children or more, were related to grater rate of domestic violence.

Table 2. The relationship of domestic violence and no domestic violence groups with some socio- demographic factors $(\mathrm{n}=600)$

\begin{tabular}{|c|c|c|c|c|}
\hline Variables & violence group & No violence group & Total & p value \\
\hline Age (women), Year, Mean (SD) & $28.96 \pm 7.19$ & $29.49 \pm 6.71$ & $29.16 \pm 7.01$ & $\mathrm{p}=0.3$ \\
\hline Age (men), Year, Mean (SD) & $36.34 \pm 7.97$ & $34.41 \pm 7.36$ & $34.38 \pm 7.74$ & $\mathrm{p}=0.9$ \\
\hline Marital Age, Year, Mean (SD) & $19.56 \pm 3.62$ & $21.07 \pm 3.92$ & $20.14 \pm 3.81$ & $\mathrm{p}<0.001$ \\
\hline Wife Fducation No (\%) & $61(16.5)$ & 29(12.6) & $90(15.0)$ & \multirow{4}{*}{$\mathrm{p}<0.001$} \\
\hline Drimon Cond & $108(29.2$ & $44(19.1)$ & $152(25.3)$ & \\
\hline Primary Secondary\& High school & $148(40.0)$ & $95(41.3)$ & $243(40.5)$ & \\
\hline Dipioma & 53(14.3) & $62(27.0)$ & $115(19.2)$ & \\
\hline Husband Education, No. (\%) & $63(17.0)$ & $17(7.40)$ & $80(13.3)$ & \multirow{4}{*}{$\mathrm{p}<0.001$} \\
\hline Primary & $126(34.1)$ & $66(28.7)$ & $92(32.0)$ & \\
\hline Secondary\& High school & $127(34.3)$ & $84(36.5)$ & $211(35.2$ & \\
\hline Diploma & $54(14.6)$ & $63(27.4)$ & $117(19.5)$ & \\
\hline \multicolumn{5}{|l|}{ Wife' Job No. (\%) } \\
\hline Housekeeper & $338(91.40)$ & $173(75.20)$ & $511(85.20)$ & \multirow[t]{2}{*}{$\mathrm{p}<0.001$} \\
\hline Employed & $32(8.60)$ & $57(24.80)$ & $89(14.80)$ & \\
\hline \multicolumn{5}{|l|}{ Husband' Job, No. (\%) } \\
\hline Employer & 213(57.6) & $119(51.7)$ & $332(55.3)$ & \multirow{3}{*}{$\mathrm{p}=0.1$} \\
\hline Employee & $36(36.7)$ & $100(43.5)$ & $236(39.3)$ & \\
\hline Unemployed & $21(5.7)$ & $11(4.8)$ & $32(5.3$ & \\
\hline \multicolumn{5}{|l|}{ Husband's Smoking, No. (\%) } \\
\hline Yes & 133(35.9) & $56(24.3)$ & $89(31.5)$ & \multirow[t]{2}{*}{$\mathrm{p}=0.003$} \\
\hline No & $237(64.1)$ & 74(75.7) & $411(68.5)$ & \\
\hline \multicolumn{5}{|c|}{ Husband's Consume Alcohol, No. (\%) } \\
\hline Yes & $35(9.5)$ & $17(7.4)$ & $52(8.7)$ & \multirow{2}{*}{$\mathrm{p}=0.3$} \\
\hline No & $335(90.5)$ & 213(92.6) & $548(91.3)$ & \\
\hline \multicolumn{5}{|l|}{ Number of children, No. (\%) } \\
\hline None & 44(11.9) & $39(17.0)$ & $83(13.8)$ & \\
\hline
\end{tabular}




\begin{tabular}{lllll}
\hline $1-2$ & $261(70.50)$ & $65(71.7)$ & $426(71.0)$ & $\mathrm{p}=0.02$ \\
$3-5$ & $63(17.0)$ & $25(10.9)$ & $88(14.7)$ & \\
$>5$ & $2(0.5)$ & $1(0.4)$ & $3(0.5)$ & \\
Husband' Satisfaction with baby sex, No. (\%) & & & & \\
Satisfaction & & & & \\
Not Satisfaction & $277(84.7)$ & $174(91.1)$ & $451(87.1)$ & $\mathrm{p}=0.03$ \\
& $50(15.3)$ & $17(8.9)$ & $67(12.9)$ & \\
Economic status in women viewspoint, No. (\%) & & & & \\
Excellent & & & & \\
Good & $10(2.7)$ & $8(3.5)$ & $18(3.0)$ & \\
Moderate (not good, not bad) & $106(28.6)$ & $88(38.3)$ & $194(32.3)$ & $\mathrm{p}=0.008$ \\
Bad & $197(53.2)$ & $117(50.9)$ & $314(52.3)$ & \\
& $57(15.4)$ & $17(7.4)$ & $74(12.3)$ & \\
\hline
\end{tabular}

One large-scale study of intimate partner violence, the National Family Violence Surveys (NFVS) of 1985, indicated that roughly one-sixth $(16 \%)$ of American couples experienced at least one physical assault on a partner within the past year. While most couples, experienced relatively minor violence (pushing, slapping, and throwing objects), 3.2 million couples experienced severe violence (kicking, punching, biting, and choking (Straus et al., 2003).

\section{Dissuasion}

The prevalence of domestic violence was high $(61.7 \%)$ and was greater than the world mean. This rate is $21.2 \%$ in Canada (Cohen \& Maclean, 2004), 46.4\% in Japanese (Hasegawa, Bessho, Hosoya, \& Deguchi, 2005), 43.7\% in USA (Plichta \& Falik, 2001), 41.4\%in Turkey (Mayda \& Akkuş, 2005) and in Egypt was 34\% (Diop-Sidibé, Campbell, \& Becker, 2006). In Iran, domestic violence was $88.9 \%$ in Kermanshah (Sadegh shokoh, Darabi Fatima, Assarzadegan Mojdeh, \& Golchin nia Abdollah, 2005) and 92\% in Bandar Abbas (Derakhshanpour et al., 2014). In present study Psychological violence was the most common form of violence $(59.7 \%)$, after that subjects were experienced physical violence $(33.2 \%)$, sexual violence $(39.3 \%)$ and the last form was sever or threatened violence $(10 \%)$ experienced, respectively. These findings are in line with other studies (Hossein, Morteza, Reza, \& Ziba, 2004; Narimani \& Agha, 2005). In Narimani and Mohamadian study, prevalence of psychological violence was reported $55.7 \%$ as the most common form, then social violence (32\%) and physical violence $(28.5 \%)$ and the last form was the sexual violence was $12.5 \%$ (Narimani \& Agha, 2005). Kramer et al (2004), reported a prevalence of physical or psychological violence $50-75 \%$ among their study's subjects (Kramer, Lorenzon, \& Mueller, 2004), but Jain (2004) a higher rate of physical violence (50\%), than psychological violence (38\%) in India (Jain, Sanon, Sadowski, \& Hunter, 2004).

Despite of this high rate of violence in various studies, it should be considered many women don't express the violence because of to be privacy information or cultural issues and in most times they are not detected by physicians in emergencies wards (Heise, Ellsberg, \& Gottmoeller, 2002). Women tolerate violence for years and don't talk about it; therefore the real rate is hidden. Fear of stigmatization, losing the children and unawareness are the most common reasons for hidden the violence (Khosravizadegan, Azizi, Khosravizadegan, \& Morvaridi, 2007).

In present study Wife and husband' Education, Wife' Job, Husband's Smoking, Number of children, Husband' Satisfaction with baby sex, and economical status by women views points were the more important factors effective on domestic violence.

Families with lower wife and husband' education, Marital Age of women and economical status in domestic violence group was found to be poorer than the non-domestic violence group.

Alesina study (2016) reported that ancient socioeconomic conditions determine social norms about gender roles, family structures and intrafamily violence which persist even when the initial conditions change. Norms about marriage patterns, living arrangements and the productive role of women are associated with contemporary violence. Also, women's contemporary economic role affects violence in a complex way which is itself related to traditional norms in ancient times and current bargaining power within the marriage (Alesina, Brioschi, \& Ferrara, 2016; Abbaspoor, 2014). 
The results of present study also showed that to be housewife, to be smoker, not to be satisfied with his babies sex (to be girl) of husband and having 3 children or more, were related to grater rate of domestic violence. These findings are in line with other studies. In most studies male addiction has been an important factor in violence against women (Hasheminasab, 2007). Education is a supportive item so with increasing the education levels in women and men, the violence rate are decreased (Hasheminasab, 2007; Hossein et al., 2004; Narimani \& Agha, 2005).

Education level not only expresses a higher social and cultural of family, but it has a positive effect on family economic status (Hasheminasab, 2007). In present study poor and moderate economic status was related to domestic violence. In other studies with decreasing the family income, the violence rate was increased. Economical problems may causes stress and in long time it could lead to do aggression (Ansari, Noroozi, Yadegari, Javaheri, \& Ansari, 2013; Dolatian, Zahiroddin, Velaie, \& Majd, 2012). Also, an increase in women's income may decrease their risk of domestic violence because their households are better off, so men feel less economic stress, which they might otherwise express through violence (Vyas \& Watts 2009). However, a man may feel his economic and household status or roles threatened, which can lead to violence as a way of expressing those feelings (Alesina, Brioschi, \& Ferrara, 2016).

\section{Conclusion}

Psychological violence is the most common form of domestic violence in Isfahan city and it is related to wife's factors such as: low marriage age, low education, unemployment, poor economical status and some husband' factors such as: education, smoking, not to be satisfied with his babies' sex (to be girl) and having 3 children or more.

\section{Acknowledgments}

This paper was one part of the MSc thesis of Mojgan Momtazpoor, and financial support was provided by the deputy vice-chancellor for research affairs of Ahvaz Jundishapur University of Medical Sciences. We wish to thank Mohammad Hossin Haghighizadeh, MSc in statistics, Department of Statistics and Mathematics, for performing the statistical analysis.

\section{Competing Interests Statement}

The authors declare that there is no conflict of interests regarding the publication of this paper.

\section{References}

Abbaspoor, Z., Moghaddam-Banaem, L., Ahmadi, F., \& Kazemnejad, A. (2014). Iranian mothers' selection of a birth method in the context of perceived norms: A content analysis study. Midwifery, 30, 804-9. http://dx.doi.org/10.1016/j.midw.2013.06.003

Alesina, A., Brioschi, B., \& Ferrara, E. (2016). Violence against women: A cross-cultural analysis for Africa. National Bureau of Economic Research. Retrieve from http://policy-practice.oxfam.org.uk/publications /womens-economic-empowerment-and-domestic-violence-links-and-lessons-for-practit-594563

Andersson, N., Ho-Foster, A., Mitchell, S., Scheepers, E., \& Goldstein, S. (2007). Risk factors for domestic physical violence: National cross-sectional household surveys in eight southern African countries. BMC Women's Health, 7, 11. http://dx.doi.org/10.1186/1472-6874-7-11

Ansari, H., Noroozi, M., Yadegari, M., Javaheri, M., \& Ansari, S. (2013). Physical, mental and sexual abuse among the married women in south eastern Iran, 2009. Bimonthly Journal of Hormozgan University of Medical Sciences, 16, 491-499.

Assembly, U. G. (1993). Declaration on the Elimination of Violence against Women. UN General Assembly.

Astin, M. C., Lawrence, K. J., \& Foy, D. W. (1993). Posttraumatic stress disorder among battered women: Risk and resiliency factors. Violence and victims, $8,17$.

Avdibegović, E., \& Sinanović, O. (2006). Consequences of domestic violence on women's mental health in Bosnia and Herzegovina. Croatian medical journal, 47, 730-741.

Campbell, J. C. (2002). Health consequences of intimate partner violence. The lancet, 359, 1331-1336. http://dx.doi.org/10.1016/S0140-6736(02)08336-8

Campbell, J., Jones, A. S., Dienemann, J., Kub, J., Schollenberger, J., O’Campo, P., \& Wynne, C. (2002). Intimate partner violence and physical health consequences. Archives of internal medicine, 162, 1157-1163. http://dx.doi.org/10.1001/archinte.162.10.1157 
Cohen, M. M., \& Maclean, H. (2004). Violence against Canadian women. BMC Women's Health, 4, S22. http://dx.doi.org/10.1186/1472-6874-4-S1-S22

Correia, I., Alves, H., Morais, R., \& Ramos, M. (2015). The legitimation of wife abuse among women: The impact of belief in a just world and gender identification. Personality and Individual Differences, 76, 7-12. http://dx.doi.org/10.1016/j.paid.2014.11.041

Council of Europe. (2012). Europe Convention on preventing and Combating Violence against Women and Domestic Violence and Explanatory Report (p. 11). Istanbul, Turkey.

Derakhshanpour, F, Mahboobi, H. R., \& Keshavarzi, S. (2014). Prevalence of domestic violence against women, Journal of Gorgan University of Medical Sciences, 16, 126-131.

Diop-Sidibé, N., Campbell, J. C., \& Becker, S. (2006). Domestic violence against women in Egypt-wife beating and health outcomes. Social science \& medicine, 62, 1260-1277. http://dx.doi.org/10.1016/j.socscimed. 2005.07.022

Dolatian, M., Gharache, M., Ahmadi, M., Shams, J., \& Alavi Majd, H. (2010). Relationship between partner abuse during pregnancy and pregnancy outcomes. Bimonthly Journal of Hormozgan University of Medical Sciences, 13, 261-9.

Dolatian, M., Zahiroddin, A., Velaie, N., \& Majd, H. A. (2012). Evaluation of prevalence of domestic violence and its role on mental health. Pajoohandeh Journal, 16, 277-283.

Faramarzi, M. (2004). Assessing the relationship between sexual violence in adults and history of physical violence. The second congress of family and sexual problems.

Garcia-Moreno, C., Jansen, H. A., Ellsberg, M., Heise, L., \& Watts, C. H. (2006). Prevalence of intimate partner violence: Findings from the WHO multi-country study on women's health and domestic violence. The lancet, 368, 1260-1269. http://dx.doi.org/10.1016/S0140-6736(06)69523-8

Guth, A. A., \& Pachter, H. L. (2000). Domestic violence and the trauma surgeon. The American Journal of Surgery, 179, 134-140. http://dx.doi.org/10.1016/S0002-9610(00)00245-2

Hasegawa, M., Bessho, Y., Hosoya, T., \& Deguchi, Y. (2005). Prevalence of intimate partner violence and related factors in a local city in Japan. (Nihon koshu eisei zasshi) Japanese journal of public health, 52, 411-421.

Hasheminasab, L. (2007). Assessment of prevalence, outcome and factors related to domestic physical violence in pregnant women referring to delivery departments of Sanandaj hospitals. Scientific Journal of Kurdistan University of Medical Sciences, 11, 32-41.

Heise, L., Ellsberg, M., \& Gottmoeller, M. (2002). A global overview of gender-based violence. International Journal of Gynecology \& Obstetrics, 78, S5-S14. http://dx.doi.org/10.1016/S0020-7292(02)00038-3

Hossein, M., Morteza, M., Reza, Z. A., \& Ziba, F. (2004). Surveying domestic violence against women in Isfahan in 2003. Medical Science Journal of Islamic Azad Univesity-Tehran Medical Branch, 14, 63-67.

Jain, D., Sanon, S., Sadowski, L., \& Hunter, W. (2004). Violence against women in India: evidence from rural Maharashtra, India. Rural remote health, 4, 304.

Jejeebhoy, S. J. (1998). Wife-beating in rural India: A husband's right? Evidence from survey data. Economic and Political weekly, 855-862.

Jewkes, R., Levin, J., \& Penn-Kekana, L. (2002). Risk factors for domestic violence: Findings from a South African cross-sectional study. Social science \& medicine, 55, 1603-1617. http://dx.doi.org/10.1016/S02779536(01)00294-5

Khosravizadegan, F., Azizi, F., Khosravizadegan, Z., \& Morvaridi, M. (2007). Study the demographic and psychology factors of domestic aggression against women in Bushehr Province. Teb-e-Jonoub, 10, 75-81.

Kramer, A., Lorenzon, D., \& Mueller, G. (2004). Prevalence of intimate partner violence and health implications for women using emergency departments and primary care clinics. Women's Health Issues, 14, 19-29. http://dx.doi.org/10.1016/j.whi.2003.12.002

Krug, E. G., Mercy, J. A., Dahlberg, L. L., \& Zwi, A. B. (2002). The world report on violence and health. The lancet, 360(9339), 1083-1088. http://dx.doi.org/10.1016/S0140-6736(02)11133-0

Krug, E., Dahlberg, L., Mercy, J., Zwi, A., \& Lozano, R. (2002). World Report on Violence and Health. Geneva. Retrieved from http://www.who.int/violenceinjuryprevention/violence/worldreport/en/fullen.pdf 
Kyriacou, D. N., Anglin, D., Taliaferro, E., Stone, S., Tubb, T., Linden, J., \& Kraus, J. F. (1999). Risk factors for injury to women from domestic violence. New England journal of medicine, 341, 1892-1898. http://dx.doi.org/10.1056/NEJM199912163412505

Machado, C., Dias, A. R., \& Coelho, C. (2010). Culture and wife abuse: An overview of theory, research, and practice.

Mailey-Morrison, K., \& Hines, D. A. (2004). Family Violence in a cultural perspective: Thousand Oaks. CA: Sage Publications.

Mayda, A. S., \& Akkuş, D. (2005). Domestic violence against 116 Turkish housewives: A field study. Women \& health, 40, 95-108. http://dx.doi.org/10.1300/J013v40n03_07

Narimani, M., \& Agha, M. H. (2005). A study of the extent of men's violence against women and its related variables among families inhabited in Ardabil city.

Panaghi, L., Dehghani, M., Abbasi, M., Mohammadi, S., \& Maleki, G. (2011). Investigating Reliability, Validity and Factor Structure of the Revised Conflict Tactics Scale. Retrieved from http://dnl.tebyan.net

Plichta, S. B., \& Falik, M. (2001). Prevalence of violence and its implications for women's health. Women's Health Issues, 11, 244-258. http://dx.doi.org/10.1016/S1049-3867(01)00085-8

Scholle, S. H., Rost, K. M., \& Golding, J. M. (1998). Physical abuse among depressed women. Journal of General Internal Medicine, 13, 607-613. http://dx.doi.org/10.1046/j.1525-1497.1998.00183.x

Sherkat, Sh. (2004). Violence against women. Women journal, 109, 64-69.

Shokoh, S., Fatima, D., Mojdeh, A., \& Abdollah, G. (2005). Assessing the sexual voilence methods in family. Second congress in familiy and sexual problems.

Straus, M. A., Hamby, S., \& Warren, W. (2003). The conflict tactics scales handbook: Revised conflict tactics scale (CTS2) and CTS: Parent-child version (CTSPC). Los Angeles, CA: Western Psychological Services.

Vyas, S., \& Charlotte, W. (2009). How Does Economic Empowerment Affect women's Risk of Intimate Partners Violence in Low and Middle Income Countries? A Systematic Review of Published Evidence. Journal of International Development, 21, 577-602. http://dx.doi.org/10.1002/jid.1500

WHO. (2013). Global and regional estimates of violence against women: prevalence and health effects of intimate partner violence and non-partner sexual violence: World Health Organization. Retrieved from http://apps.who.int/iris/bitstream/10665/85239/1/9789241564625_eng.pdf

\section{Copyrights}

Copyright for this article is retained by the author(s), with first publication rights granted to the journal.

This is an open-access article distributed under the terms and conditions of the Creative Commons Attribution license (http://creativecommons.org/licenses/by/3.0/). 